\title{
TOURISM VILLAGE DEVELOPMENT STRATEGY BASED ON LOCAL RESOURCES IN AYUNAN VILLAGE, ABIANSEMAL DISTRICT, BADUNG REGENCY
}

\author{
I Putu Susila ${ }^{1}$, I Ketut Sumantra ${ }^{*}{ }^{凶}$ (iD) , A.A Sudiana ${ }^{1}$, Ni Putu Pandawani ${ }^{1}$ \\ *1 Post Graduate Program in Regional Development Planning and Environmental Management, \\ Mahasaraswati Denpasar University, Denpasar-Bali, Indonesia
}

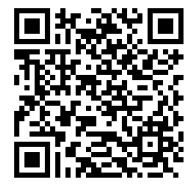

DOI: https://doi.org/10.29121/granthaalayah.v9.i2.2021.3432

Article Type: Research Article

Article Citation: I Putu Susila, I Ketut Sumantra, A.A Sudiana, and Ni Putu Pandawani. (2021). TOURISM VILLAGE DEVELOPMENT STRATEGY BASED ON LOCAL RESOURCES IN AYUNAN VILLAGE, ABIANSEMAL DISTRICT, BADUNG REGENCY. International Journal of Research -GRANTHAALAYAH, 9(2), 108-119.

https://doi.org/10.29121/granthaa layah.v9.i2.2021.3432

Received Date: 04 January 2021

Accepted Date: 25 February 2021

Keywords:

Development Strategy

QSPM Analysis

Tourism

Local Resources

\section{ABSTRACT}

Ayunan Village has a variety of tourism potentials, which are worthy of being developed as an attractive tourist destination in the future. To achieve this, an appropriate management strategy is needed to develop the tourist area of the Ayunan village. The objective of this research was: 1) Exploring and assessing local resources in Ayunan village, 2) Identify and analyze community perceptions about the development of tourist villages, 3) Formulating a local resource-based tourism village development strategy. The research method was used observation, interviews, and questionnaires. SWOT analysis is used to determine the tourism village development strategy and Quantitative Strategic Planning Matrix (QSPM) analysis was used to rank development priorities. There are eight alternative strategies to develop Ayunan village as a tourist destination: a) Destination planning, b) Development of tourist attractions, c) Development of tourist facilities, d) Travel promotion or marketing, e) Community approach, f) Mapping tourism potential, g) Establishment of Tourism village community groups, h) Increase in human resources. The priority strategies base on QSPM analysis were: rank 1st was marketing or promoting. The Rank 2st Approach to the community to participate in supporting the development of tourism villages. Rank 3st Planning tourist destinations and rank 4th were increasing human resources.

\section{INTRODUCTION}

Tourism is Bali's leading sector. This sector occupies a very strategic position in determining economic growth (Puspitadewi and Rahayu, 2018). On the other hand, even though tourism has been recognized as a stimulator to drive the economy, mass tourism also hides several things that are rarely disclosed and calculated so that it is very difficult to trace their role or disadvantage (Arida, 2009). The reduction in paddy fields and at the same time influencing the existence of Subak (irrigation system for paddy fields on Bali island) is a side effect (Windia, 2013), as well as indirectly affecting food availability (Andayani et.al., 2018) and decreasing biodiversity (Primdahl et al., 2013). Realizing this fact, many countries that rely on the tourism sector have begun to look at tourism development that is small in terms of quantity but has good quality in terms of local communities and terms of tourists because it is based on local resources (Sati, 2018).

(C) 2021 The Author(s). This is an open access article distributed under the terms of the Creative Commons Attribution License, which permits unrestricted use, distribution, and reproduction in any medium, provided the original author and source are credited. 
The development of a tourist village based on local resources is in line with the three principles of sustainable tourism development developed by the World Tourism Organization (WTO) namely: ecological sustainability, sociocultural continuity, and economic sustainability, both for current and future generations (Suwena, 2010; Maheswari and Sariani, 2019), thus the need for the development of a local resource-based tourism village in the Ayunan village to create a sustainable tourism village, can improve the economic welfare of local communities and also to protect, maintain and preserve local wisdom (Ruzic and Sutic, 2014; Wismayani et.al., 2019; Anggun et.al., 2019).

Tourism is considered as an alternative in the economic sector to accelerate poverty reduction in Indonesia and it is believed not only to be able to become a mainstay sector in the effort to increase the country's foreign exchange but also able to alleviate poverty (Yoeti, 2008; Raju et al., 2019). This is in line with what is stated in the Law of the Republic of Indonesia No. 10 of 2009 on Tourism, that the implementation of tourism is aimed at increasing national income in the framework (a) Increase the welfare and prosperity of the people. (b) Expanding and equalizing business and employment opportunities. (c) Encouraging regional development. (d) Introducing and utilizing tourist objects and attractions in Indonesia. (e) Fostering love for the country and (f) Strengthening friendship between nations.

A tourist attraction is everything unique, beautiful, and values in the form of the diversity of natural resources, culture, and man-made products that are the target or purpose of tourist visits. Development strategies through tourism components such as accessibility, accommodation, attraction, activities, and what is known as the 5A concept and the ultimate goal of achieving effective tourism development goals with the condition of developing quality products and services according to the timeframe, namely the short, medium and long term (Mistriani, 2019). Tourist attractions are grouped into three parts, namely: natural tourist attractions, cultural tourism attractions, and artificial tourist attractions. Tourism village development can be done through good promotion, further enhance cooperation with various related parties, conducting education and training programs in the field of tourism and languages for human resources (Astuti, 2017).

Tourism development on the island of Bali began in 1980, initiated by several areas such as Kuta, Sanur, Nusa Dua, and Ubud, it continues to expand to other areas to remote villages with the term tourist village. It is evident from the table of the number of foreign tourist visits to Bali by month, from 1982-2019 (BPS, 2019) shows that the number of foreign tourist arrivals in Bali has increased every year with an average growth of $11.22 \%$, with the highest growth rate occurred in 2004 amounting to $48.23 \%$. This is due to the attractiveness of Bali which amazes tourists both because of its culture, customs, diverse arts, and enchanting natural beauty.

Ayunan Village is located in Abiansemal District, Badung Regency, precisely between Taman Ayun and Sangeh attractions, which is $20 \mathrm{~km}$ from the city of Denpasar, the topography of the flat settlement extends along the main road with a building arrangement based on Balinese architecture (asta kosala kosali) and the downstream part is a rice field area (subak Ayunan) and the upstream part is a plantation (subak Abian) as the main life support for the community. To the west flows the Dangkang river which is a source of irrigation for the subak Ayunan and in the east, the Pendet river flows. The natural conditions are still beautiful, the neatly arranged terraced rice fields are the main attraction. These natural and cultural resources have the potential to be used as natural tourism or ecotourism. The majority of the livelihoods of the Ayunan villagers are agriculture and livestock in a broad sense. This research was conducted to raise the potential of Ayunan village to be developed into a local resource-based tourism village. However, until now, the local resource potential of Ayunan village is unknown. Likewise, how is the community's perception of the development of a tourist village, and what strategies are needed for village development. The purpose of this research was to formulate a development strategy and determine strategic priorities in the development of local resource-based tourism villages in Ayunan Village, Abiansemal District, Badung Regency.

\section{MATERIALS AND METHODS}

The research location is in the village of Ayunan, Abiansemal sub-district, Badung regency which was determined purposively because it is a strategic area located between tourism villages that have been and are developing. This research was conducted to explore and study the tourism potential in the Ayunan village, including community perceptions of the development of tourist villages, reality conditions in the observed research area are following existing phenomena and are prepared based on scientific studies, and finally formulating an alternative strategy. Data collection techniques used were questionnaires, interviews, observation, literature study, and 
Tourism Village Development Strategy Based on Local Resources in Ayunan Village, Abiansemal District, Badung Regency

documentation of stakeholders and community leaders. The analysis technique used in formulating a local resourcebased tourism village development strategy is a qualitative descriptive analysis which includes:

1) Analysis to explore and study local resources in Ayunan village, Abiansemal district, Badung regency. This analysis uses the Participatory Rural Appraisal (PRA) method by involving the local community to determine the potential for tourism by distributing questionnaires and interviews to community leaders.

2) Analysis of community perceptions about the development of Ayunan village into a tourist village. In this analysis, the result is the identification of community perceptions of the development of Ayunan village into a tourist village based on the opinions of stakeholders and the community regarding the aspects to be studied. The method used is the descriptive method with questionnaires and in-depth interviews with the community.

3) SWOT analysis in formulating a local resource-based strategy for village development of Ayunan based on the strengths, weaknesses, opportunities, and threats that exist in the research area. The results of the SWOT analysis will formulate an alternative strategy for developing Ayunan village into a tourist village.

4) QSPM matrix is used to evaluate and select the best strategy that best fits the internal and external environment that is owned by the tourism manager (David 2011). The alternative strategy that has the largest total value in the QSPM matrix is the best strategy to be applied to Tourism Village Management. QSPM analysis is the final stage analysis used in determining the priority choice of marketing strategy.

There are 6 steps to create a matrix QSPM, namely:

1) Compile a list of strengths, weaknesses, opportunities, and threats that are common to the SWOT Matrix.

2) Give weight to strengths, weaknesses, opportunities, and threats. This weight is the same as the weights assigned to the IFE and EFE matrices.

3) Developing alternative strategies to be evaluated. Set the Alternactiveness Scores (AS) ranging from 1 to 4. The value 1 is unattractive, $2=$ mildly attractive, $3=$ fairly attractive, $4=$ very attractive.

4) Calculate the total attractiveness value (Total Attractiveness Scores - TAS), then multiply the weight by the value of attraction (AS).

5) Calculate the total value of attraction value (STAS). The alternative strategy that has the greatest total value is the best.

\section{RESULTS AND DISCUSSIONS}

\subsection{LOCAL RESOURCES OF THE VILLAGE OF AYUNAN}

Natural potential includes: 1) The beauty of subak Ayunan with views of Mount Agung and Mount Batukaru, of 51 respondents 47 or $92.16 \%$ of respondents agreed, only 4 or $7.84 \%$ of respondents said they did not agree. At the subak Ayunan, educational tours were also developed, where tourists could learn to hoe, plow, and plant rice. With a panoramic view of cool rice fields, it is very suitable for developing eco tracking. 2) Jungle tracking, 51 or $100 \%$ of respondents agree. Along the Munduk Tebe river from the Bale Subak to the Subak Ayunan dam, tourists can enjoy attractions such as face painters, katik sate craftsmen, Pancoran dedari, Bukit Buung temple, and other attractions such as fishing ponds and village reservoirs can be developed. 3) Honey bee farm, 51 or $100 \%$ of respondents agree. According to respondents, the development of honey bee farms needs to be developed from upstream in the form of bee cultivation to downstream, such as making packaging so that it becomes a special attraction for tourists and marketing its honey so that it can increase community income and open new jobs. b) Cultural potential includes 1) Tjok Agung Tresna Museum, 51 or $100 \%$ of respondents answered agree. In this museum, there are many paintings, sculptures, and ancient agricultural tools such as tengale, lampit, tulud, and fishing tools such as bubu, sau, and others. The entrance to the museum is a very unique kori agung reaching a height of 20 meters. In the back area, there is a stage for performance events. 2) Bukit Buung Temple, 51 or $100 \%$ of respondents agreed. This temple is a symbol of the failure of the forest expansion (niskala) because it was caught. This temple is also believed to be able to ask for healing for fracture sufferers through the stakeholders at this temple. 3) Pancoran Dedari, 51 or $100 \%$ of respondents agreed. This pancoran comes from springs that never dry out during the long dry season and the water doesn't have much water during the rainy season. The water remains clear even though there are rice field processing activities around the Pancoran. This shower water is believed to cure eye diseases. 4) Making ceremonial 
offerings by the Serati Banten group, respondents' answers 43 or $84.71 \%$ agree, 8 or $15.69 \%$ of respondents disagree, every banjar in Ayunan village has a group of serati banten which produces banten for use during ceremonies at temples and in people's homes. For people who cannot or do not have time to make offerings, they can order from Serati at various prices depending on the size of the offering. Making ceremonial offerings by the Serati offerings to synergize the BUPDA (Badan Usaha Padruen Desa Adat) and the BUMDes. c) Potential crafts include: 1) Painter Group, 51 or $100 \%$ of respondents agreed. Painting craftsmen in Banjar Badung are gathered in the "Dukuh Art Studio", here there are several streams of painting, such as face painting and modern art (abstract, decorative, and others). 2) Wood carving art groups, 51 or $100 \%$ of respondents agree. Every banjar in Ayunan village has a group of wood carving craftsmen, starting from the carving of the saka, pementang, door, dedeleg, and others. Especially in the Geriya Banjar, craftsmen are carving Pratima statues. 3) Melela sand carving craftsman, 51 or $100 \%$ of respondents agree. These craftsmen are centered in Banjar Ambengan, buildings that use melela sand such as temples, objections, traditional bale decorations, and bale bandung. This group of melting sand craftsmen is well known throughout Bali, especially West Bali. Melela sand carving prices vary depending on the quality of the carving. 4) Katik sate craftsmen group, 51 or $100 \%$ of respondents agree. Making katik sate using machine tools so that it can produce more. The material of the katik sate is bamboo taken from the community's agricultural products. The marketing of katik sate has spread to Kalimantan and Lampung. d) Potential local wisdom includes 1) Traditional institutions/organizations such as (subak, desa adat, banjar adat, and sekehe-sekehe sebun), 50 or $98.04 \%$ of respondents agreed, 1 or $1.96 \%$ answered disagree. All of these existing organizations are organizations from ancient times that should always be preserved to maintain a harmonious life order in the village of Ayunan. 2) Norms such as (awig-awig, perarem), 50 or $98.04 \%$ of respondents agreed, 1 or $1.96 \%$ of respondents answered disagree. To bind the community in carrying out daily life, it is regulated by awig-awig or perarem. Awig-awig has been made since ancient times and is made improvements every few years depending on the current situation. 3) Ritual (religious ceremony), 50 or $98.04 \%$ of respondents answered agree, 1 or $1.96 \%$ of respondents answered disagree. There are a lot of religious ceremonies in the village of Ayunan, such as galungan, kuningan, nyepi, temple rituals, and others. This ceremony is very interesting if it is witnessed by tourists, especially foreign tourists. Respondent data tabulation can be seen in Table 1

Table 1: Tourism potential in Ayunan Village

\begin{tabular}{|c|c|c|c|c|c|c|c|c|c|c|c|c|c|c|}
\hline \multirow[t]{2}{*}{ Description } & \multicolumn{3}{|c|}{$\begin{array}{l}\text { Pot. of Nature } \\
\text { Tourism }\end{array}$} & \multicolumn{4}{|c|}{$\begin{array}{l}\text { Pot. for Cultural } \\
\text { tourism }\end{array}$} & \multicolumn{4}{|c|}{ Pot. for craft tourism } & \multicolumn{3}{|c|}{$\begin{array}{l}\text { Pot. Local } \\
\text { wisdom }\end{array}$} \\
\hline & 1 & 2 & 3 & 4 & 5 & 6 & 7 & 8 & 9 & 10 & 11 & 12 & 13 & 14 \\
\hline A & 47 & 51 & 51 & 51 & 51 & 51 & 43 & 51 & 51 & 51 & 51 & 50 & 50 & 50 \\
\hline$\%$ & 92,1 & 100 & 100 & 100 & 100 & 100 & 84,3 & 100 & 100 & 100 & 100 & 98 & 98 & 98 \\
\hline NA & 4 & 0 & 0 & 0 & 0 & 0 & 8 & 0 & 0 & 0 & 0 & 1 & 1 & 1 \\
\hline$\%$ & 7,8 & 0 & 0 & 0 & 0 & 0 & 15,6 & 0 & 0 & 0 & 0 & 1,9 & 1,9 & 1,9 \\
\hline
\end{tabular}

Source: 2020 research results

Description: A: Agree; NA: Disagree; Pot: Potential

1) The beauty of subak Ayunan with views of Mount Batukaru and Mount Agung

2) Jungle tracking

3) Honey bee farm and culinary

4) Tjok Agung Tresna painting museum in Badung banjar

5) Bukit Buung Temple

6) Pancoran dedari

7) Serati offerings group the making of ceremonial offerings is managed by BUMDes

8) Dukuh Art Studio with face painters

9) Pretima carving group

10) Melela sand carving group

11) Katik sate craftsmen group

12) Traditional organizations/institutions (desa adat, banjar adat, subak)

13) Applicable norms such as awig-awig, perarem

14) Ritual (religious ceremony) 
Supporting facilities and infrastructure for tourism in the Ayunan village, such as public toilets and trash bins, are not yet available. Parking space is available but needs a further arrangement. Traditional food stalls/shops still need additional products sold. Lodging or homestay already exists but still needs to be added. Accessibility in the form of main roads (district roads) in good condition, supporting roads (environmental roads) in good condition, other roads to destinations (papingization) are quite good. Institutions such as pokdarwis need to be established and existing institutions need to be fostered with human resources through training in a language and on tourism.

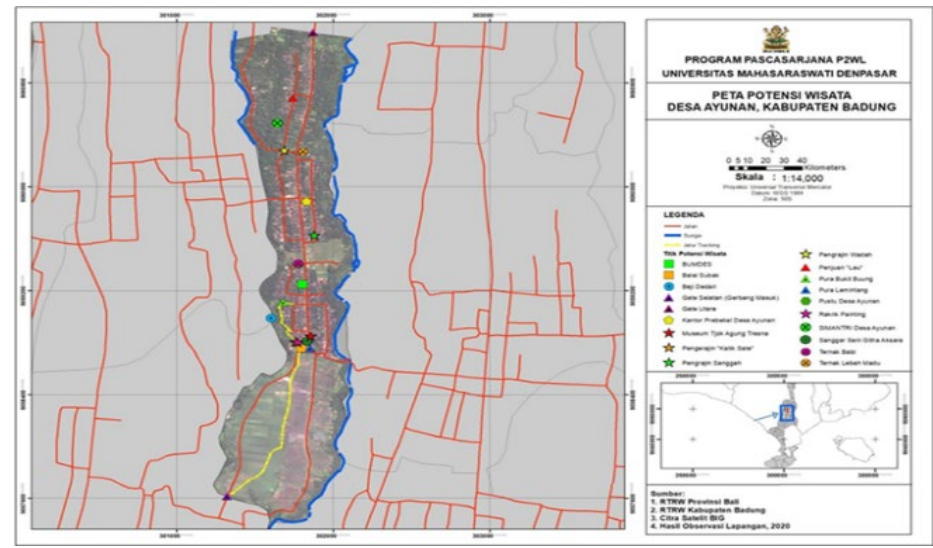

Figure 1: Map of tourism potential based on local resources in Ayunan village

\subsection{PERCEPTIONS AND ATTITUDES OF THE COMMUNITY}

To know for sure the public perception of the development of Ayunan village into a tourist village, namely using descriptive analysis by distributing questionnaires and in-depth interviews. The respondent's answer shows that all $(100 \%)$ of the respondents agree and strongly agree with the development of Ayunan village as a tourism village according to the nine questions submitted through the questionnaire, namely: a) Ayunan Village is located at the Taman Ayun and Sangeh tourist route, b) Can increase community income, c) Can empower local wisdom, d) The younger generation can attend education or training, e) The policy of the Ayunan village government is very large, f) Institutions are very important in the development of tourist villages, g) Customary institutions and service institutions must work together, h) Supporting infrastructure needs to be equipped, i) Promotion or marketing needs to be held. The development of the Ayunan village into a tourist village requires support from all components, including the government, the business world, and the community. The development of tourism villages in Ayunan should pay attention to environmentally friendly and sustainable development (Table 2).

Table 2: Perceptions and attitudes of the Ayunan village community towards developing Ayunan village as a tourist village

\begin{tabular}{|c|c|c|c|c|c|c|c|c|c|}
\hline Description & \multicolumn{1}{|c|}{ Attitudes and perceptions of society } \\
\hline Description & A & b & c & d & e & f & G & h & i \\
\hline A & 10 & 11 & 15 & 10 & 29 & 14 & 14 & 13 & 13 \\
\hline$\%$ & 19,6 & 21,5 & 29,6 & 19,6 & 56,8 & 27,4 & 27,4 & 25,5 & 25,5 \\
\hline SA & 41 & 40 & 36 & 41 & 22 & 37 & 37 & 38 & 38 \\
\hline$\%$ & 89,4 & 78.6 & 70,6 & 80,4 & 43,1 & 72,5 & 72,5 & 74,5 & 74,5 \\
\hline
\end{tabular}

Source: 2020 primary data analysis

Description: A: Agree, SA: Strongly Agree

1) The development of a tourist village in Ayunan is very suitable because it is located on the tourist route between Taman Ayun and Sangeh.

2) With the development of a tourist village in Ayunan Village, it can increase community income.

3) The development of a tourist village in Ayunan will empower local wisdom such as the banjar adat, desa adat, subak, sanggar-sanggar and sekehe sebun. 
4) In developing a tourism village in Ayunan village, it is necessary to hold education or training for the young generation to prepare local workers in the field of tourism

5) The policy of the Ayunan village government towards developing tourism villages in Ayunan is very large

6) Institutions are very important in developing tourist villages

7) Official agencies and customary institutions must work together in the management of tourist villages

8) If the Ayunan is used as a tourist village, supporting infrastructure needs to be equipped, such as parking, toilets, restaurants, homestays.

9) For tourists to visit the Ayunan village, it needs promotion or marketing.

The results of this study are in line with the findings of Maheswari, and Sariani, (2019).

\subsection{A TOURISM VILLAGE DEVELOPMENT STRATEGY BASED ON LOCAL RESOURCES IN THE VILLAGE OF AYUNAN}

To formulate a local resource-based tourism village development strategy is carried out through a SWOT analysis technique based on the strengths, weaknesses, opportunities, and threats that exist in the research area that has been carried out (Table 3).

Table 3: Strategies in developing tourism villages based on local wisdom

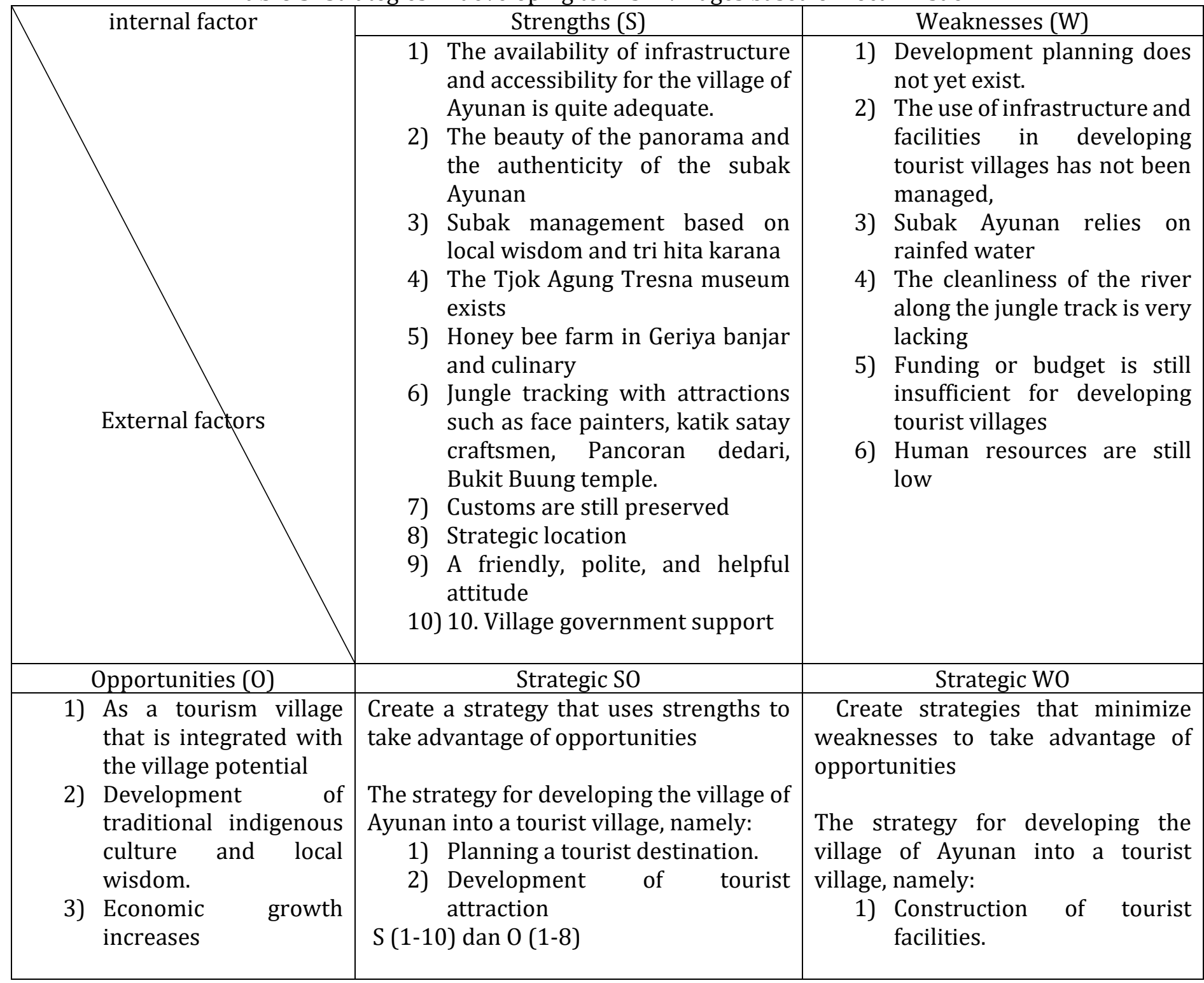


Tourism Village Development Strategy Based on Local Resources in Ayunan Village, Abiansemal District, Badung Regency

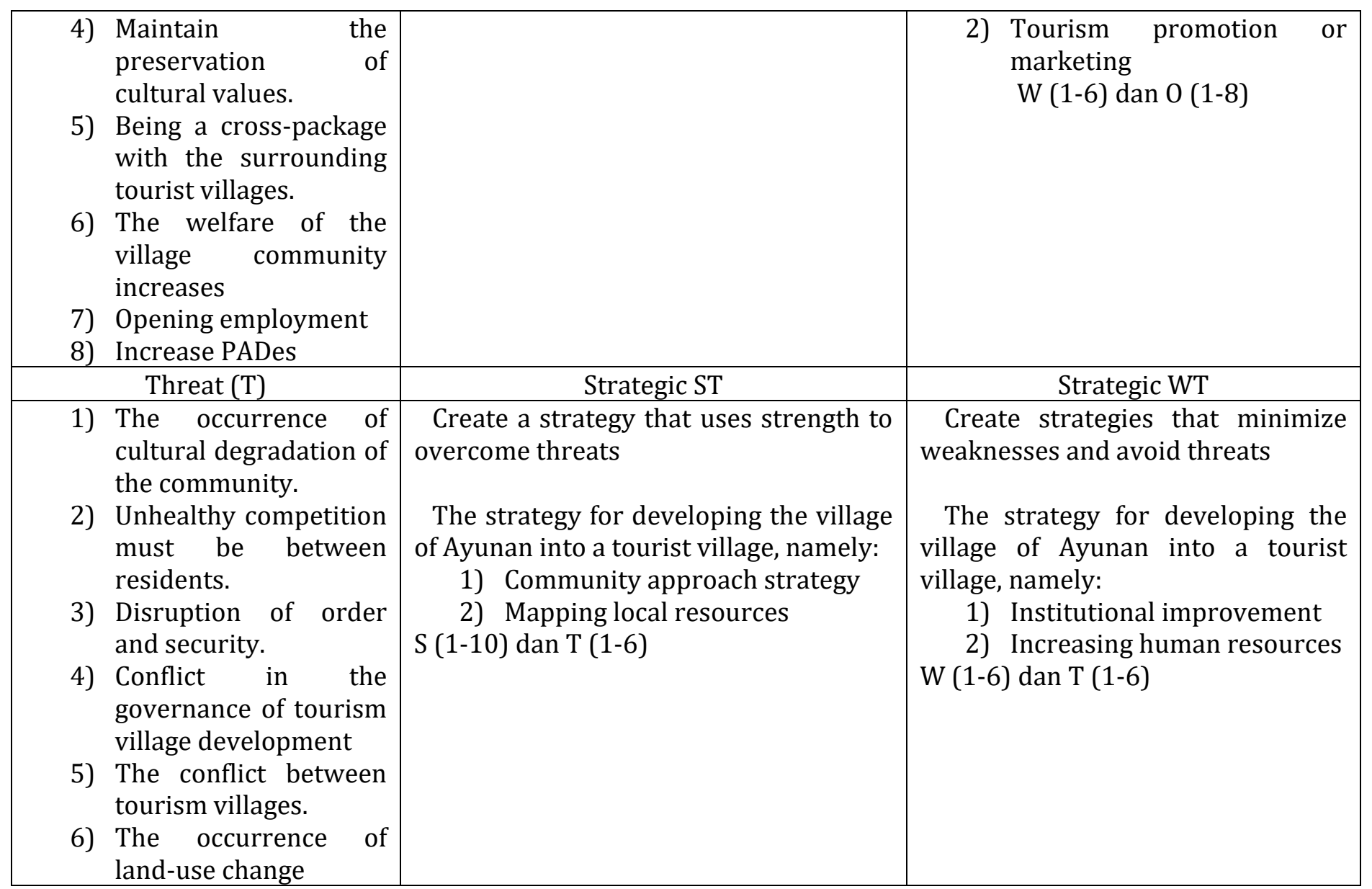

Source: Data Analysis, 2020

Based on the results of the SWOT analysis that has been carried out, strategies for developing local resourcebased tourism villages are formulated, namely:

1) Planning for tourist destinations based on local resources in Ayunan village (SO)

2) Development of tourist attractions in the village of Ayunan (SO)

3) Construction of tourist facilities that are not yet available (WO)

4) Marketing or tourism promotion through the website so that the Ayunan village is more quickly and widely recognized by tourists (WO)

5) Approaches to the community to participate in supporting the development of tourist villages (ST)

6) Mapping tourism potential to make it easier for tourists to reach. (ST)

7) Establishment of Pokdarwis and improvement of existing institutions. (WT)

8) Increasing human resources in the management of tourism development (WT)

1) Development strategies by using strengths to take advantage of opportunities (SO) by using the following programs: 1) Arranging and expanding the collection of paintings at the Tjok Agung Tresna museum and holding dance performances every time there is a tourist visit. 2) Maintain the management of the Ayunan subak so that it is based on local wisdom and Tri Hita Karana. Creating educational tours for tourists such as learning to plant rice, hoeing, plowing, and others. 3) Developing honey bee cultivation to increase the income of the breeders. Educate tourists so they can learn to cultivate honey bees. 4) Holding regular cooperation to clean up trash and bushes along with the jungle track. 5) Adding attractions along with jungle trackings such as fishing ponds and village reservoirs. 6) Serati offerings can educate tourists to learn to make ceremonial offerings. 
2) Development strategies by minimizing weaknesses to get opportunities (WO) by implementing programs, among others: 1) Improve infrastructure such as the continuation of the Munduk Kangin and Munduk Tengah roads until they penetrate the asphalt road. 2) Improve the management of existing infrastructure to benefit the people of Ayunan village. 3) Efforts to add water sources to irrigate the subak of Ayunan, among others, with the alternative of making trowongan from the tukad pendet, making reservoirs before the Ayunan dam, drilling wells, and others in the hope of increasing agricultural output. 4) Complete tourism facilities such as culinary delights, toilets, and lodging (homestay). 5) Propose funding to the government or investors so that the tourism village in Ayunan can be quickly realized.6) Doing promotions or marketing such as: collaborating with tour guides, Travel Agencies (BPW) and Association of Travel Agents (ASITA), hotels and restaurants, establishing a TIC (Tourism Information Center), cultural festivals, social media, print media, WEB Badung Regency and others.

3) Strategy development by using strength to overcome threats (ST) by implementing the program: 1) Conduct coaching and training for the young generation to have qualified abilities. 2) Provide education to farmers not to sell their land or minimize land conversion. 3) Maintain and preserve customs so that cultural degradation does not occur. 4) Maintain traditional organizations complete with their norms and rituals such as religious ceremonies. 5) Maintain a friendly, polite, helpful attitude so that conflicts do not occur between residents and between tourist villages. 6) Increase the income and welfare of the community so that security and order problems can be guaranteed.

4) Development strategies by minimizing weaknesses to avoid threats by implementing programs including 1) Establishment of Tourism village community groups (Pokdarwis). 2) Maintain and develop organizations that are related to tourism so that tourism in the village of Ayunan develops rapidly. 3) Increase human resources by training and tourism education. 4) Outreach for tourism awareness and charm. 5) Fostering and growing and developing local products.

\subsection{QSP Matrix (Quantitative Strategic Planning Matrix)}

The final stage in strategy formulation is the decision stage. The tool used at the decision stage in this study is the QSPM matrix. This QSPM matrix will select the priority strategy to be recommended to the Ayunan village manager. To find out which strategy is prioritized, the TAS value is used, which is the highest score of total attractiveness. The TAS value is obtained from the multiplication of the weight of each internal and external factor with the attractiveness score (AS). The attractiveness score itself was obtained from the results of the brainstorming between researchers and community leaders (Ayunan village officials) as decision-makers in developing Ayunan village as a tourist village. The QSPM matrix that has been compiled by researchers can be seen in Table 4.

Tabel 4: Matriks QSPM

\begin{tabular}{|c|c|c|c|c|c|c|c|c|c|c|c|c|c|c|c|c|c|}
\hline \multirow{3}{*}{ Key factor } & \multirow{3}{*}{$\begin{array}{l}\text { Wei } \\
\text { ght }\end{array}$} & \multicolumn{16}{|c|}{ Strategi alternatif } \\
\hline & & \multicolumn{2}{|c|}{$\begin{array}{l}\text { Strategi } \\
\text { c } 1\end{array}$} & \multicolumn{2}{|c|}{$\begin{array}{l}\text { Strategi } \\
\text { c2 }\end{array}$} & \multicolumn{2}{|c|}{$\begin{array}{l}\text { Strategi } \\
\text { c3 }\end{array}$} & \multicolumn{2}{|c|}{$\begin{array}{l}\text { Strategi } \\
\text { c4 }\end{array}$} & \multicolumn{2}{|c|}{$\begin{array}{l}\text { Strate } \\
\text { gic5 }\end{array}$} & \multicolumn{2}{|c|}{$\begin{array}{l}\text { Strateg } \\
\text { ic } 6\end{array}$} & \multicolumn{2}{|c|}{$\begin{array}{l}\text { Strate } \\
\text { gic } 7 \\
\end{array}$} & \multicolumn{2}{|c|}{$\begin{array}{c}\text { Strategi } \\
8\end{array}$} \\
\hline & & $\begin{array}{l}\mathrm{A} \\
\mathrm{S}\end{array}$ & TAS & $\begin{array}{l}\mathrm{A} \\
\mathrm{S}\end{array}$ & TAS & $\begin{array}{l}\mathrm{A} \\
\mathrm{S}\end{array}$ & TAS & $\begin{array}{l}\mathrm{A} \\
\mathrm{S}\end{array}$ & TAS & $\begin{array}{l}\mathrm{A} \\
\mathrm{S}\end{array}$ & $\begin{array}{c}\mathrm{TA} \\
\mathrm{S}\end{array}$ & $\begin{array}{l}\mathrm{A} \\
\mathrm{S}\end{array}$ & TAS & $\begin{array}{l}\mathrm{A} \\
\mathrm{S}\end{array}$ & $\begin{array}{c}\text { TA } \\
\text { S }\end{array}$ & $\begin{array}{l}\mathrm{A} \\
\mathrm{S}\end{array}$ & TAS \\
\hline Strengths & & & & & & & & & & & & & & & & & \\
\hline $\begin{array}{l}\text { Availability of adequate } \\
\text { infrastructure for the } \\
\text { village of Ayunan }\end{array}$ & $\begin{array}{c}0.06 \\
8\end{array}$ & 3 & $\begin{array}{c}0.20 \\
3\end{array}$ & 2 & $\begin{array}{c}0.13 \\
5\end{array}$ & 4 & $\begin{array}{c}0.27 \\
0\end{array}$ & 4 & $\begin{array}{c}0.27 \\
0\end{array}$ & 3 & $\begin{array}{l}0.2 \\
03\end{array}$ & 2 & $\begin{array}{l}0.1 \\
35\end{array}$ & 4 & $\begin{array}{l}0.2 \\
70\end{array}$ & 3 & $\begin{array}{c}0.20 \\
3\end{array}$ \\
\hline $\begin{array}{l}\text { The beauty of the } \\
\text { panorama and the beauty } \\
\text { of the subak Ayunan }\end{array}$ & $\begin{array}{c}0.07 \\
2\end{array}$ & 3 & $\begin{array}{c}0.21 \\
7\end{array}$ & 4 & $\begin{array}{c}0.28 \\
9\end{array}$ & 3 & $\begin{array}{c}0.21 \\
7\end{array}$ & 4 & $\begin{array}{c}0.28 \\
9\end{array}$ & 2 & $\begin{array}{l}0.1 \\
45\end{array}$ & 2 & $\begin{array}{l}0.1 \\
45\end{array}$ & 3 & $\begin{array}{l}0.2 \\
17\end{array}$ & 2 & $\begin{array}{c}0.14 \\
5\end{array}$ \\
\hline $\begin{array}{l}\text { Subak management based } \\
\text { on local wisdom and tri } \\
\text { hita karana }\end{array}$ & $\begin{array}{c}0.07 \\
4\end{array}$ & 2 & $\begin{array}{c}0.14 \\
8\end{array}$ & 2 & $\begin{array}{c}0.14 \\
8\end{array}$ & 2 & $\begin{array}{c}0.14 \\
8\end{array}$ & 3 & $\begin{array}{c}0.22 \\
2\end{array}$ & 2 & $\begin{array}{l}0.1 \\
48\end{array}$ & 3 & $\begin{array}{l}0.2 \\
22\end{array}$ & 2 & $\begin{array}{l}0.1 \\
48\end{array}$ & 2 & $\begin{array}{c}0.14 \\
5\end{array}$ \\
\hline $\begin{array}{c}\text { The Tjok Agung Tresna } \\
\text { museum exists }\end{array}$ & $\begin{array}{c}0.07 \\
6\end{array}$ & 2 & $\begin{array}{c}0.15 \\
2\end{array}$ & 3 & $\begin{array}{c}0.22 \\
8\end{array}$ & 3 & $\begin{array}{c}0.22 \\
8\end{array}$ & 4 & $\begin{array}{c}0.30 \\
4\end{array}$ & 2 & $\begin{array}{l}0.1 \\
52\end{array}$ & 3 & $\begin{array}{l}0.2 \\
28\end{array}$ & 3 & $\begin{array}{l}0.2 \\
28 \\
\end{array}$ & 3 & $\begin{array}{c}0.22 \\
8\end{array}$ \\
\hline $\begin{array}{c}\text { Honey bee farm in Geriya } \\
\text { banjar and culinary lawar } \\
\text { bee }\end{array}$ & $\begin{array}{c}0.07 \\
1\end{array}$ & 3 & $\begin{array}{c}0.21 \\
4\end{array}$ & 3 & $\begin{array}{c}0.21 \\
4\end{array}$ & 2 & $\begin{array}{c}0.14 \\
3\end{array}$ & 3 & $\begin{array}{c}0.21 \\
4\end{array}$ & 3 & $\begin{array}{l}0.2 \\
14\end{array}$ & 3 & $\begin{array}{c}0.2 \\
14\end{array}$ & 3 & $\begin{array}{l}0.2 \\
14\end{array}$ & 2 & $\begin{array}{c}0.14 \\
3\end{array}$ \\
\hline
\end{tabular}


Tourism Village Development Strategy Based on Local Resources in Ayunan Village, Abiansemal District, Badung Regency

\begin{tabular}{|c|c|c|c|c|c|c|c|c|c|c|c|c|c|c|c|c|c|}
\hline $\begin{array}{l}\text { Jungle tracking with } \\
\text { attractions such as face } \\
\text { painters, katik sate } \\
\text { craftsmen, Pancoran } \\
\text { dedari, Bukit Buung } \\
\text { Temple }\end{array}$ & $\begin{array}{c}0.07 \\
8\end{array}$ & 3 & $\begin{array}{c}0.23 \\
3\end{array}$ & 3 & $\begin{array}{c}0.23 \\
3\end{array}$ & 3 & $\begin{array}{c}0.23 \\
3\end{array}$ & 3 & $\begin{array}{c}0.23 \\
3\end{array}$ & 3 & $\begin{array}{l}0.2 \\
33\end{array}$ & 3 & $\begin{array}{l}0.2 \\
33\end{array}$ & 3 & $\begin{array}{l}0.2 \\
33\end{array}$ & 3 & $\begin{array}{c}0.23 \\
3\end{array}$ \\
\hline $\begin{array}{c}\text { Customs are still } \\
\text { preserved }\end{array}$ & $\begin{array}{c}0.07 \\
2 \\
\end{array}$ & 2 & $\begin{array}{c}0.14 \\
5 \\
\end{array}$ & 1 & $\begin{array}{c}0.07 \\
2 \\
\end{array}$ & 1 & $\begin{array}{c}0.07 \\
2 \\
\end{array}$ & 2 & $\begin{array}{c}0.14 \\
5 \\
\end{array}$ & 2 & $\begin{array}{l}0.1 \\
45 \\
\end{array}$ & 1 & $\begin{array}{l}0.0 \\
72 \\
\end{array}$ & 2 & $\begin{array}{l}0.1 \\
45 \\
\end{array}$ & 1 & $\begin{array}{c}0.07 \\
2 \\
\end{array}$ \\
\hline $\begin{array}{l}\text { The village is strategically } \\
\text { located on a tourist route }\end{array}$ & $\begin{array}{c}0.07 \\
1\end{array}$ & 2 & $\begin{array}{c}0.14 \\
2\end{array}$ & 1 & $\begin{array}{c}0.07 \\
1\end{array}$ & 1 & $\begin{array}{c}0.07 \\
1\end{array}$ & 2 & $\begin{array}{c}0.14 \\
2\end{array}$ & 2 & $\begin{array}{l}0.1 \\
42\end{array}$ & 1 & $\begin{array}{l}0.0 \\
71\end{array}$ & 1 & $\begin{array}{l}0.0 \\
71\end{array}$ & 2 & $\begin{array}{c}0.14 \\
2\end{array}$ \\
\hline $\begin{array}{l}\text { A friendly, polite, helpful } \\
\text { attitude }\end{array}$ & $\begin{array}{c}0.07 \\
1\end{array}$ & 1 & $\begin{array}{c}0.01 \\
7\end{array}$ & 2 & $\begin{array}{c}0.14 \\
2\end{array}$ & 2 & $\begin{array}{c}0.14 \\
2\end{array}$ & 2 & $\begin{array}{c}0.14 \\
2\end{array}$ & 2 & $\begin{array}{l}0.1 \\
42\end{array}$ & 1 & $\begin{array}{l}0.0 \\
71\end{array}$ & 1 & $\begin{array}{l}0.0 \\
71\end{array}$ & 2 & $\begin{array}{c}0.14 \\
2\end{array}$ \\
\hline $\begin{array}{c}\text { Village government } \\
\text { support }\end{array}$ & $\begin{array}{c}0.07 \\
8 \\
\end{array}$ & 3 & $\begin{array}{c}0.23 \\
3 \\
\end{array}$ & 3 & $\begin{array}{c}0.23 \\
3 \\
\end{array}$ & 3 & $\begin{array}{c}0.23 \\
3 \\
\end{array}$ & 3 & $\begin{array}{c}0.23 \\
3 \\
\end{array}$ & 3 & $\begin{array}{l}0.2 \\
33 \\
\end{array}$ & 1 & $\begin{array}{l}0.0 \\
78 \\
\end{array}$ & 2 & $\begin{array}{l}0.1 \\
55\end{array}$ & 2 & $\begin{array}{c}0.15 \\
5\end{array}$ \\
\hline \multicolumn{18}{|l|}{ Weaknesses } \\
\hline $\begin{array}{r}\text { Development plan } \\
\text { does not yet exi }\end{array}$ & $\begin{array}{c}0.04 \\
4\end{array}$ & 2 & $\begin{array}{c}0.08 \\
8\end{array}$ & 2 & $\begin{array}{c}0.08 \\
8\end{array}$ & 2 & $\begin{array}{c}0.08 \\
8\end{array}$ & 2 & $\begin{array}{c}0.08 \\
8\end{array}$ & 3 & $\begin{array}{l}0.1 \\
32\end{array}$ & 2 & $\begin{array}{l}0.0 \\
88\end{array}$ & 3 & $\begin{array}{l}0.1 \\
32\end{array}$ & 2 & $\begin{array}{c}0.08 \\
8\end{array}$ \\
\hline $\begin{array}{l}\text { The use of infrastructure } \\
\text { in the development of } \\
\text { tourism villages has not } \\
\text { been managed }\end{array}$ & $\begin{array}{c}0.03 \\
9\end{array}$ & 2 & $\begin{array}{c}0.07 \\
9\end{array}$ & 2 & $\begin{array}{c}0.07 \\
9\end{array}$ & 2 & $\begin{array}{c}0.07 \\
9\end{array}$ & 3 & $\begin{array}{c}0.11 \\
8\end{array}$ & 2 & $\begin{array}{l}0.0 \\
79\end{array}$ & 2 & $\begin{array}{l}0.0 \\
79\end{array}$ & 3 & $\begin{array}{l}0.1 \\
18\end{array}$ & 2 & $\begin{array}{c}0.07 \\
9\end{array}$ \\
\hline $\begin{array}{r}\text { Subak Ayu } \\
\text { rainf }\end{array}$ & $\begin{array}{c}0.04 \\
7 \\
\end{array}$ & 1 & $\begin{array}{c}0.04 \\
7 \\
\end{array}$ & 2 & $\begin{array}{c}0.09 \\
3 \\
\end{array}$ & 2 & $\begin{array}{c}0.09 \\
3 \\
\end{array}$ & 3 & $\begin{array}{c}0.14 \\
0\end{array}$ & 3 & $\begin{array}{l}0.1 \\
40 \\
\end{array}$ & 2 & $\begin{array}{l}0.0 \\
93 \\
\end{array}$ & 2 & $\begin{array}{l}0.0 \\
93 \\
\end{array}$ & 2 & $\begin{array}{c}0.09 \\
3 \\
\end{array}$ \\
\hline $\begin{array}{l}\text { The cleanliness of the } \\
\text { trench/trench along the } \\
\text { jungle track is very dirty }\end{array}$ & $\begin{array}{c}0.04 \\
6\end{array}$ & 1 & $\begin{array}{c}0.04 \\
6\end{array}$ & 1 & $\begin{array}{c}0.04 \\
6\end{array}$ & 2 & $\begin{array}{c}0.09 \\
1\end{array}$ & 3 & $\begin{array}{c}0.13 \\
7\end{array}$ & 3 & $\begin{array}{l}0.1 \\
37\end{array}$ & 2 & $\begin{array}{l}0.0 \\
91\end{array}$ & 2 & $\begin{array}{l}0.0 \\
91\end{array}$ & 2 & $\begin{array}{c}0.09 \\
1\end{array}$ \\
\hline $\begin{array}{l}\text { Funding/budget is still } \\
\text { lacking }\end{array}$ & $\begin{array}{c}0.04 \\
5\end{array}$ & 2 & $\begin{array}{c}0.09 \\
0\end{array}$ & 2 & $\begin{array}{c}0.09 \\
0\end{array}$ & 2 & $\begin{array}{c}0.09 \\
0\end{array}$ & 3 & $\begin{array}{c}0.13 \\
5\end{array}$ & 3 & $\begin{array}{l}0.1 \\
35\end{array}$ & 2 & $\begin{array}{l}0.0 \\
90\end{array}$ & 2 & $\begin{array}{l}0.0 \\
90\end{array}$ & 2 & $\begin{array}{c}0.09 \\
0\end{array}$ \\
\hline $\begin{array}{c}\text { Human resources are still } \\
\text { low }\end{array}$ & $\begin{array}{c}0.04 \\
9 \\
\end{array}$ & 3 & $\begin{array}{c}0.14 \\
8 \\
\end{array}$ & 3 & $\begin{array}{c}0.14 \\
8 \\
\end{array}$ & 1 & $\begin{array}{c}0.04 \\
9 \\
\end{array}$ & 3 & $\begin{array}{c}0.14 \\
8 \\
\end{array}$ & 3 & $\begin{array}{l}0.1 \\
48 \\
\end{array}$ & 3 & $\begin{array}{l}0.1 \\
48 \\
\end{array}$ & 2 & $\begin{array}{l}0.0 \\
99 \\
\end{array}$ & 4 & $\begin{array}{c}0.19 \\
7 \\
\end{array}$ \\
\hline \multicolumn{18}{|l|}{ Opportunities } \\
\hline $\begin{array}{l}\text { As a tourism village that is } \\
\text { integrated with the village } \\
\text { potential }\end{array}$ & $\begin{array}{c}0.09 \\
2\end{array}$ & 1 & $\begin{array}{c}0.09 \\
2\end{array}$ & 1 & $\begin{array}{c}0.09 \\
2\end{array}$ & 1 & $\begin{array}{c}0.09 \\
2\end{array}$ & 2 & $\begin{array}{c}0.18 \\
5\end{array}$ & 1 & $\begin{array}{l}0.0 \\
92\end{array}$ & 1 & $\begin{array}{l}0.0 \\
92\end{array}$ & 1 & $\begin{array}{l}0.0 \\
92\end{array}$ & 1 & $\begin{array}{c}0.09 \\
2\end{array}$ \\
\hline $\begin{array}{c}\text { Development of } \\
\text { traditional indigenous } \\
\text { culture and local wisdom }\end{array}$ & $\begin{array}{c}0.08 \\
9\end{array}$ & 2 & $\begin{array}{c}0.17 \\
8\end{array}$ & 2 & $\begin{array}{c}0.17 \\
8\end{array}$ & 2 & $\begin{array}{c}0.17 \\
8\end{array}$ & 2 & $\begin{array}{c}0.17 \\
8\end{array}$ & 2 & $\begin{array}{l}0.1 \\
78\end{array}$ & 3 & $\begin{array}{l}0.2 \\
68\end{array}$ & 2 & $\begin{array}{l}0.1 \\
78\end{array}$ & 2 & $\begin{array}{c}0.17 \\
8\end{array}$ \\
\hline $\begin{array}{l}\text { Economic growth } \\
\text { increases }\end{array}$ & $\begin{array}{c}0.09 \\
2\end{array}$ & 2 & $\begin{array}{c}0.18 \\
4\end{array}$ & 3 & $\begin{array}{c}0.27 \\
5\end{array}$ & 2 & $\begin{array}{c}0.18 \\
4\end{array}$ & 3 & $\begin{array}{c}0.27 \\
5\end{array}$ & 2 & $\begin{array}{l}0.1 \\
84\end{array}$ & 2 & $\begin{array}{l}0.1 \\
84\end{array}$ & 2 & $\begin{array}{l}0.1 \\
84\end{array}$ & 2 & $\begin{array}{c}0.18 \\
4\end{array}$ \\
\hline $\begin{array}{c}\text { Maintain the preservation } \\
\text { of cultural values }\end{array}$ & $\begin{array}{c}0.08 \\
6\end{array}$ & 2 & $\begin{array}{c}0.17 \\
2\end{array}$ & 1 & $\begin{array}{c}0.08 \\
6\end{array}$ & 1 & $\begin{array}{c}0.08 \\
6\end{array}$ & 2 & $\begin{array}{c}0.17 \\
2\end{array}$ & 2 & $\begin{array}{l}0.1 \\
72\end{array}$ & 2 & $\begin{array}{l}0.1 \\
72\end{array}$ & 1 & $\begin{array}{l}0.0 \\
86\end{array}$ & 2 & $\begin{array}{c}0.17 \\
2\end{array}$ \\
\hline $\begin{array}{l}\text { Being a cross-package } \\
\text { with the surrounding } \\
\text { tourist villages }\end{array}$ & $\begin{array}{c}0.08 \\
4\end{array}$ & 1 & $\begin{array}{c}0.08 \\
4\end{array}$ & 1 & $\begin{array}{c}0.08 \\
4\end{array}$ & 2 & $\begin{array}{c}0.16 \\
8\end{array}$ & 3 & $\begin{array}{c}0.25 \\
3\end{array}$ & 2 & $\begin{array}{l}0.1 \\
68\end{array}$ & 1 & $\begin{array}{l}0.0 \\
84\end{array}$ & 1 & $\begin{array}{l}0.0 \\
84\end{array}$ & 1 & $\begin{array}{c}0.08 \\
4\end{array}$ \\
\hline $\begin{array}{c}\text { The welfare of the village } \\
\text { community increases }\end{array}$ & $\begin{array}{c}0.09 \\
0 \\
\end{array}$ & 3 & $\begin{array}{c}0.27 \\
0 \\
\end{array}$ & 2 & $\begin{array}{c}0.18 \\
0 \\
\end{array}$ & 2 & $\begin{array}{c}0.18 \\
0 \\
\end{array}$ & 3 & $\begin{array}{c}0.27 \\
0 \\
\end{array}$ & 3 & $\begin{array}{l}0.2 \\
70 \\
\end{array}$ & 2 & $\begin{array}{l}0.1 \\
80 \\
\end{array}$ & 2 & $\begin{array}{l}0.1 \\
80 \\
\end{array}$ & 2 & $\begin{array}{c}0.18 \\
0 \\
\end{array}$ \\
\hline Opening & $\begin{array}{c}0.09 \\
2\end{array}$ & 2 & $\begin{array}{c}0.18 \\
4\end{array}$ & 2 & $\begin{array}{c}0.18 \\
4\end{array}$ & 2 & $\begin{array}{c}0.18 \\
4\end{array}$ & 3 & $\begin{array}{c}0.27 \\
5\end{array}$ & 3 & $\begin{array}{l}0.2 \\
75\end{array}$ & 2 & $\begin{array}{l}0.1 \\
84\end{array}$ & 2 & $\begin{array}{l}0.1 \\
84\end{array}$ & 3 & $\begin{array}{c}0.27 \\
5\end{array}$ \\
\hline Incre & $\begin{array}{c}0.09 \\
2 \\
\end{array}$ & 2 & $\begin{array}{c}0.18 \\
4 \\
\end{array}$ & 2 & $\begin{array}{c}0.18 \\
4 \\
\end{array}$ & 2 & $\begin{array}{c}0.18 \\
4 \\
\end{array}$ & 3 & $\begin{array}{c}0.27 \\
5 \\
\end{array}$ & 2 & $\begin{array}{l}0.1 \\
84 \\
\end{array}$ & 2 & $\begin{array}{l}0.1 \\
84 \\
\end{array}$ & 2 & $\begin{array}{l}0.1 \\
84 \\
\end{array}$ & 2 & $\begin{array}{c}0.18 \\
4 \\
\end{array}$ \\
\hline \multicolumn{18}{|l|}{ Threat } \\
\hline $\begin{array}{c}\text { The occurrence of cultural } \\
\text { degradation of the } \\
\text { community }\end{array}$ & $\begin{array}{c}0.04 \\
7\end{array}$ & 1 & $\begin{array}{c}0.04 \\
7\end{array}$ & 2 & $\begin{array}{c}0.09 \\
5\end{array}$ & 1 & $\begin{array}{c}0.04 \\
7\end{array}$ & 2 & $\begin{array}{c}0.09 \\
6\end{array}$ & 2 & $\begin{array}{l}0.0 \\
95\end{array}$ & 1 & $\begin{array}{l}0.0 \\
47\end{array}$ & 1 & $\begin{array}{l}0.0 \\
47\end{array}$ & 1 & $\begin{array}{c}0.04 \\
7\end{array}$ \\
\hline $\begin{array}{c}\text { Unfair business } \\
\text { competition among } \\
\text { residents }\end{array}$ & $\begin{array}{c}0.04 \\
4\end{array}$ & 1 & $\begin{array}{c}0.04 \\
4\end{array}$ & 2 & $\begin{array}{c}0.08 \\
7\end{array}$ & 1 & $\begin{array}{c}0.04 \\
4\end{array}$ & 3 & $\begin{array}{c}0.13 \\
1\end{array}$ & 1 & $\begin{array}{l}0.0 \\
44\end{array}$ & 1 & $\begin{array}{l}0.0 \\
44\end{array}$ & 1 & $\begin{array}{l}0.0 \\
44\end{array}$ & 1 & $\begin{array}{c}0.04 \\
4\end{array}$ \\
\hline $\begin{array}{c}\text { Disruption of order and } \\
\text { security }\end{array}$ & $\begin{array}{c}0.04 \\
8 \\
\end{array}$ & 2 & $\begin{array}{c}0.09 \\
6 \\
\end{array}$ & 1 & $\begin{array}{c}0.04 \\
8 \\
\end{array}$ & 2 & $\begin{array}{c}0.09 \\
6 \\
\end{array}$ & 3 & $\begin{array}{c}0.14 \\
4 \\
\end{array}$ & 2 & $\begin{array}{l}0.0 \\
96 \\
\end{array}$ & 2 & $\begin{array}{l}0.0 \\
96 \\
\end{array}$ & 1 & $\begin{array}{l}0.0 \\
48 \\
\end{array}$ & 2 & $\begin{array}{c}0.09 \\
6 \\
\end{array}$ \\
\hline $\begin{array}{c}\text { Conflict in the } \\
\text { management of tourism }\end{array}$ & $\begin{array}{c}0.04 \\
6\end{array}$ & 2 & $\begin{array}{c}0.09 \\
2\end{array}$ & 1 & $\begin{array}{c}0.04 \\
6\end{array}$ & 1 & $\begin{array}{c}0.04 \\
6 \\
\end{array}$ & 2 & $\begin{array}{c}0.09 \\
2 \\
\end{array}$ & 2 & $\begin{array}{l}0.0 \\
92 \\
\end{array}$ & 1 & $\begin{array}{l}0.0 \\
46 \\
\end{array}$ & 1 & $\begin{array}{l}0.0 \\
46 \\
\end{array}$ & 2 & $\begin{array}{c}0.09 \\
2 \\
\end{array}$ \\
\hline
\end{tabular}


I Putu Susila, I Ketut Sumantra, A.A Sudiana, and Ni Putu Pandawani

\begin{tabular}{|c|c|c|c|c|c|c|c|c|c|c|c|c|c|c|c|c|c|}
\hline $\begin{array}{l}\text { village development } \\
\text { among residents }\end{array}$ & & & & & & & & & & & & & & & & & \\
\hline $\begin{array}{l}\text { The conflict between } \\
\text { tourism villages }\end{array}$ & $\begin{array}{c}0.04 \\
9\end{array}$ & 1 & $\begin{array}{c}0.04 \\
9\end{array}$ & 1 & $\begin{array}{c}0.04 \\
9\end{array}$ & 1 & $\begin{array}{c}0.04 \\
9\end{array}$ & 2 & $\begin{array}{c}0.09 \\
9\end{array}$ & 1 & $\begin{array}{l}0.0 \\
49\end{array}$ & 1 & $\begin{array}{l}0.0 \\
49\end{array}$ & 1 & $\begin{array}{l}0.0 \\
49\end{array}$ & 1 & $\begin{array}{c}0.04 \\
9\end{array}$ \\
\hline $\begin{array}{l}\text { The occurrence of land- } \\
\text { use change }\end{array}$ & $\begin{array}{c}0.04 \\
8\end{array}$ & 3 & $\begin{array}{c}0.14 \\
4\end{array}$ & 2 & $\begin{array}{c}0.09 \\
6\end{array}$ & 2 & $\begin{array}{c}0.09 \\
6\end{array}$ & 3 & $\begin{array}{c}0.14 \\
4\end{array}$ & 3 & $\begin{array}{l}0.1 \\
44\end{array}$ & 3 & $\begin{array}{l}0.1 \\
44\end{array}$ & 2 & $\begin{array}{l}0.0 \\
96\end{array}$ & 2 & $\begin{array}{c}0.09 \\
6\end{array}$ \\
\hline TOTAL & $\begin{array}{c}2.00 \\
0\end{array}$ & & $\begin{array}{c}4.07 \\
4\end{array}$ & & $\begin{array}{c}3.99 \\
3\end{array}$ & & $\begin{array}{c}3.88 \\
1\end{array}$ & & $\begin{array}{c}5.54 \\
7\end{array}$ & & $\begin{array}{l}4.5 \\
69\end{array}$ & & $\begin{array}{l}3.8 \\
31\end{array}$ & & $\begin{array}{l}3.8 \\
77\end{array}$ & & $\begin{array}{c}4.02 \\
2\end{array}$ \\
\hline
\end{tabular}

Source: Data Analysis, 2020

Note: AS Alternactiveness Scores. TAS: Total Attractiveness Scores

From the QSP Matrix (Tabel 4), it can be concluded that from the 8 (eight) alternative strategies, priority strategies are selected which must be prioritized by tourism managers in the Ayunan village in the following order:

1) Marketing or promoting tourism through the website so that the Ayunan village is more quickly and widely recognized by tourists with a total attraction value of 5.547 ,

2) An approach to the community to participate in supporting the development of a tourist village with a total attraction value of 4.569 .

3) Planning a tourist destination based on local resources in the village of Ayunan with a total attraction value of 4.074

4) Increasing human resources in the management of tourism development with a total attraction value of 4.022

\section{CONCLUSIONS \& RECOMMENDATIONS}

1) Tourism potential in Ayunan village based on local resources were:

- Natural tourism potential was: 1) Beautiful and sustainable panoramic view of the subak Ayunan rice fields, 2) Jungle tracking with attractions of face painters, katik satay craftsmen, pancoran dedari, Bukit Buung temple, 3) Honey bee farm.

- Cultural tourism, namely: 1) Tjok Agung Tresna Museum, 2) Bukit Buung Temple, 3) Pancoran Dedari, 4) Making ceremonial offerings by the Serati Banten.

- Potential for handicraft tourism, namely: 1) Dukuh Art Studio with face painters, 2) Pretima carving craftsmen, 3) Fine sand carving craftsmen, 4) katik satay craftsmen group.

- The tourism potential of local wisdom, namely: 1) Traditional organizations or institutions such as subak, desa adat, banjar adat, and sekehe sebum, 2) Applicable norms such as awig-awig, perarem, 3) Ritual (religious ceremony).

2) The community strongly agrees that the village of Ayunan was developed as a tourist village for the 9 reasons stated, namely: a) The location of the village is strategic, b) It can increase community income, c) Empowers local wisdom, d) Opportunities for the involvement of the younger generation to build the village, e) Government support, f) Institutions are very important in the development of tourist villages, g) Customary institutions and service agencies must work together, h) Supporting infrastructure needs to be completed, i) Promotion or marketing needs to be held.

3) Based on the results of the SWOT analysis, strategies for developing a tourism village based on local resources in Ayunan village are formulated, namely: a) Planning for tourist destinations based on local resources, b) Development of tourist attractions. c) Construction of tourist facilities that are not yet available. d) Marketing or promotion of tourism through the website. e) Approach to the community to participate in supporting the development of tourism villages. f) Mapping tourism potential to make it easier for tourists to reach. g) Establishment of Tourism village community groups. h) To increase human resources in managing tourism development. The priority strategies base on QSPM analysis were: rank $1^{\text {st }}$ was marketing or promoting tourism through the website. The Rank $2^{\text {st }}$ Approach to the community to participate in supporting the development of tourism villages. Rank 3st Planning for tourist destinations based on local resources and Rank $4^{\text {st }}$ was increasing human resources in managing tourism development. The results of these findings can be recommended that the tourism village manager immediately did tourist destinations and develop tourist attractions as well as carry out tourism promotions or marketing. The 
Tourism Village Development Strategy Based on Local Resources in Ayunan Village, Abiansemal District, Badung Regency

village government of Ayunan should conduct outreach to the community and provide training in tourism management and development.

\section{SOURCES OF FUNDING}

This research received no specific grant from any funding agency in the public, commercial, or not-for-profit sectors.

\section{CONFLICT OF INTEREST}

The author have declared that no competing interests exist.

\section{ACKNOWLEDGMENT}

Thank you to the Director of Postgraduate Program at Mahasaraswati Denpasar University for the support, Village Head, and the community of Ayunan Village for their assistance in data collection.

\section{REFERENCES}

[1] Astuti, N. N. S. (2016). Potential Development Strategy for Mengesta Village as an Ecotourism-Based Tourism Village. Soshum: Journal of Social and Humanities, VOL. 6, NO. 1, MARCH 2016, 113-122.

[2] Andayani, W., P. Nugroho, D.O Hapsari. 2018. Study of Urban Agricultural Development Potential in Semarang City. Research and Technology Vo. I2, No 2, 2016, 55-68.

[3] Arida, Nyoman Sukma. 2009. Paving the Bali Ecotourism Road (Development Process, Local Participation, and Challenges of Ecotourism in Three Ancient Balinese Villages). Denpasar: Udayana University Press

[4] Puspita Sari, C and Sri Rahayu (2018). Carrying Capacity of Gancik Hill Top for Ecotourism Development in Boyolali District. E3S Web of Conferences 73. 02006.2018.

[5] Raju, M. S., Udayashankar, N., \& Seshadri, S. (2019). Measuring Tourism Carrying Capacity: A MultiDimensional Framework for Assessment. In Environmental Impacts of Tourism in Developing Nations (pp. 42-67). IGI Global.

[6] Ruzic, V., and Sutic, B. (2014). Ecological risks of expansive tourist development in protected areas - case study: Plitvice Lakes National Park. Coll. Antropol. 38: 241-248.

[7] Sati, V. P. (2018). Carrying capacity analysis and destination development: a case study of Gangotri tourists/pilgrims' circuit in the Himalaya. Asia Pacific Journal of Tourism Research. 23(3): 312-322

[8] Maheswari, A. I. A., \& Sariani, N. L. P. (2019). Public and Tourists' Perception of the Development of Sida Tapa Tourism Village as a Community-Based Tourism Village in Banjar District, Buleleng Regency. Media for Scientific Development, Vol. 13, No 12, 2019. 1813-1822.

[9] Hastuti, S. P., \& Khotimah, N. (2008). Model Pengembangan Desa Wisata Berbasis Kearifan Lokal Sebagai Strategi Pengentasan Kemiskinan di Lereng Merapi Kabupaten Sleman Daerah Istimewa Yogyakarta. Laporan Penelitian. https://eprints.uny.ac.id/22394/1/artikel\%20desa\%20wisata.pdf

[10] David, F. R. 2011. Strategic Management Concepts and Cases. by Pearson Education, Inc., publishing as Prentice Hall. 694.

[11] Windia, Wayan. 2013. Penguatan Budaya Subak Melalui Pemberdayaan Petani. Jurnal Kajian Bali.Vol. 03No.02, 2013, 137-158.

[12] Undang-Undang Republik Indonesia No. 10 Tahun 2009 tentang Kepariwisataan https://jdih.kemenkeu.go.id/fullText/2009/10TAHUN2009UU.HTM

[13] Central Bureau of Statistics of the Province of Bali in 2019.

[14] Wismayani, Alit Wiswasta, K. Sumantra. 2019. Development of Goa Lawah Temple as a Spiritual Tourism Based on Local Wisdom. International Journal of Contemporary Research and Review. Vol.10, No.2, February 2019, 21395-21400. 
[15] Anggun Sasmita, A.A, K, Sudiana, K Sumantra, M, Wena, 2019. Empowering Indigenous Peoples in the Development of Culture-Based Travel Destinations in Kutuh Village - Badung Regency. International Journal of Contemporary Research and Review. Vol.10, No.2, February 2019, 21267-21272.

[16] Suwena, K., 2010. Sustainable Tourism in the Vortex of the Global Crisis. Market: Publisher Udayana University Press. 150.

[17] Yoety, O. A. (2008). Tourism economics: introduction, information and applications. Kompas Book Publisher. 